\title{
COMMENT
}

\section{A PROJECT FOR IMPROVEMENT OF TRUST LAW*}

\author{
GEORGE G. BOGERT $\dagger$
}

I WANT to advance the thesis that trust men have a great opportunity to take the lead at this time in revaluing and readjusting trust law; that the time is ripe for taking an inventory of trust law, state by state, through a cooperative research and discussion project, and curing weaknesses and defects by statute.

There are several reasons for this belief. The first is that Anglo-American trust law is well developed and mature. It is not a branch of the law brought into being by recent social, mechanical, political or economic changes. It is not like the law of aeronautics, the undeveloped by-product of recent invention; or like the law of administrative agencies, in a state of flux and expansion as a result of recent governmental and political movements. The law of trusts is the outcome of more than 300 years of English and I 50 years of American case law. Its principles have been announced, expounded, and developed in thousands of opinions by chancellors and probate judges. Almost every conceivable question which could arise in the creation and administration of trusts has received some attention from some court in some Anglo-American jurisdiction, and most of the more important problems have been elucidated by numerous well reasoned decisions which present all shades of opinion.

This judicial evolution of trust law has occurred in widely varying states of economic and social condition. It began with simple medieval society, continued during the beginnings of the industrial revolution, and has been extended into the complex life of our time. In its initial stages it was adapted exclusively to the individual trustee, and for the last fifty years or so it has increasingly taken account of the corporate trustee. It started with the voluntary trustee, the friend or relative who acted as a matter of accommodation, and it has continued in an age when the operation of trusts is at least theoretically a business run for profit. This development has been carried forward in eras of prosperity and expansion, and at other times the courts have been called upon to pass upon the acts of trustees committed in times of depression and financial emergency. In the course of its maturing the trust has been employed for an increasing number of purposes. The earlier cases discussed it as a device in marriage or family settlements, but more recently the courts have been called on to consider it also in real estate financing, the conduct of business, the liquidation

* An address delivered at the Mid-Continent Trust Conference, Chicago, October 27, I939.

$\dagger$ James Parker Hall Professor of Law, University of Chicago. 
of embarrassed debtor's estates, the handling of insurance policies and their proceeds, the voting of corporate stock, the minimizing of tax burdens, and in other situations.

Surely it is easier and more profitable to inventory and evaluate a well developed and mature body of law than the law of a novel and incipient topic; and surely on this score the law of trusts qualifies for reconsideration and revaluation.

Secondly, the law of trusts is not only mature but it is well organized. By this I mean that the great mass of decisions and statutes constituting the raw material of trust law has been carefully examined, digested, classified, assembled, and criticized by qualified specialists. The chaff of obsolete, overruled, and redundant decisions, and of repealed statutes has been winnowed out. The residue of valid and important cases has been organized into a symmetrical whole, which is capable of being mastered and applied with a minimum of effort. In some fields of the law little of this sifting, analyzing, and consolidating has occurred. One who explores a subject of this sort feels as if he were entering a maze or a morass. These are the topics which have not excited the interest of the investigator and writer. The restatement of the law has not touched them and the text books on them are often of the head note type. To inventory them with a view to statutory improvement would involve enormous preliminary spade work.

As examples of unorganized topics one might refer to conflict of laws before the restatement and Beale's book, and to trust receipts. Before the restatement and before Beale, conflict of laws was treated as a separate subject in only a few law schools, the texts on it were slight and incomplete, and it was not given separate discussion in the American digest system, but here and there throughout the whole system were scattered paragraphs labelled "What Law Governs." Consequently ignorance and confusion were rampant.

As for trust receipts, their use is of comparatively recent origin, they have no home in the digest system, but are compelled to seek shelter under the protection of Sales, Estoppel, Principal and Agent, and Chattel Mortgages. There are a few articles and sections in books about them, but no unified, collected treatment. Perhaps it would not be an exaggeration to say that most lawyers do not know whether a trust receipt involves a true trust of the equitable type or not.

But with trusts we have the restatement, published in 1935, and Professor Scott's work, issued in 1939; and my own treatise, issued in 1935, with a supplement in 1938 and a second supplement expected in 1940; as well as other useful texts. In addition, in the states of Arkansas, Colorado, Massachusetts, Mississippi, New Hampshire, Ohio, Pennsylvania, Rhode Island and Texas, state annotations have been prepared for the Restatement of the Law of Trusts, showing how local decisions agree or disagree with the restatement, section by section. These state annotations are being prepared in all other states, and are in process of publication in California, Kansas, and Missouri. Further- 
more, there are numerous classic articles on trust topics by famous legal scholars, as, for example, by Ames, Holmes, Costigan, and Harlan F. Stone.

As a result of this, and much other valuable material from the pens of lawyers, trust men and teachers, the status of the law of trusts in a given jurisdiction is relatively easy to discover. It is possible to obtain rather quickly and completely a comparison of trust law in the various states, and to learn the eccentricities, irregularities and missing elements in the trust law of this state or that. And so I may say that the satisfactory status of books on trust law as it is in I939 forms an argument for consideration of the merit of that law. Ten or twenty years from now, after thousands of other cases and statutes are added, trust law may have returned to its former state of uncertainty, confusion, and complexity.

Thirdly, in trust law we have an organized group of lawyers and businessmen constantly engaged in the administration of the law who are greatly interested in the development of that law and in its adaptability to present needs. In trust officers and trust counsel we have a unit which can bring to bear on a reconsideration of trust law much practical and theoretical information. They have organization, enthusiasm, and they know how trusts are working in actual life. The law of fiduciaries is their main interest. That it shall be modern, efficient and fair is a vital interest to them.

In many departments of the law no such group exists. In such fields the development of the law is not the principal interest of a group of businessmen or lawyers. Many have a slight but none a major interest. Imagine trying to secure organized assistance from practicing specialists in revaluing the law of torts or contracts. There are no professional tortfeasors or tortfeasees; no small, compact units of contract makers or breakers. All business is now and then in contact with tort or contract law, but no businessmen and few lawyers make a specialty of the administration of either branch of the law.

This front-line, operating knowledge of how trust law is working, so easily available through organizations of trust men and bankers, would be a great asset in any study of trust law with the idea of possible slight reforms here and there. It would guarantee that revision statutes would not be based merely on printed appellate court opinions. The existence of the organized, professional trust administrator is a strong argument for the feasibility of a revaluation project.

Fourthly, there has been in the trust field extensive statutory experimentation which would be very helpful to a group considering a corrective law in a given state. A great variety of trust problems have been attacked by legislators and often with different approaches and procedures. A state committee desiring to work this or that reform could almost always find one or more statutes already in existence and aimed at the same result. It could be learned how these statutes have worked. They might serve as models or they might prove horrible examples of the wrong approach. 
In some fields the common law has been left almost intact. For example, the rules relating to the formation and enforcement of contracts are to be found almost entirely in decisions. It has not often seemed necessary to change or reform by statute. The use of fictions and the aid of equity have no doubt been influences which have obviated to some extent the need of statutory reforms. But the last century has shown a strong tendency toward the revamping and remodelling of parts of trust law by act of the legislature. Starting in England about $185^{\circ}$ we find a tendency to govern the conduct of the trustee by legislative enactment which culminated in the Trustee Act of $1925,{ }^{x}$ a statute of $7 x$ sections. There are also other acts regarding Judicial Trustees, ${ }^{2}$ Charitable Trusts, ${ }^{3}$ the Public Trustee, 4 Mortmain, ${ }^{5}$ and the use of trusts in the landholding system. ${ }^{6}$ These schemes for modifying the common equity of trusts have been widely copied in Canada, Australia, New Zealand and other parts of the British Empire.

The American legislatures have also served as active laboratories for the testing of new ideas in trust creation and administration. In general they have taken new tacks and not copied the English statutes.

The New York Revised Statutes of 1830 sought to limit trusts of real property to four purposes, abolish purchase money resulting trusts as deceptive and dangerous, and limit suspension of the power of alienation to two lives in being. ${ }^{7}$ As construed they made the ordinary trust to collect and pay over income suspend the power of alienation and, thus, they have limited the duration of the typical trust to two lives. The New York system was followed in Wiscon$\sin ^{8}{ }^{8}$ Michigan ${ }^{9}$ and Minnesota, ${ }^{\text {,o }}$ and used as the basis for the trust portion of the Field Code in California ${ }^{\text {II }}$ which was copied at least in part in Montana, ${ }^{\mathrm{xz}}$ North Dakota, ${ }^{13}$ Oklahoma, ${ }^{14}$ and South Dakota. ${ }^{x 5}$ The rigors of this original New York system have been softened by statutes in all these states in recent years.

As examples of other trust statutes which have been adopted in a part of our union, I may refer to the Uniform Fiduciaries Act of I922, prepared by Professor Scott, covering the topic of participation by third parties in a breach of

$x_{5}$ Geo. V, c. $x 9$ (I925).

${ }^{2} 59 \& 60$ Vict., c. 35 (1896).

3 I5 \& I6 Geo. V, c. 27 (I925).

7 For the present successors of these statutes, see N.Y. Personal Property Law and N.Y. Real Property Law.

${ }^{8}$ Wis. Stat. (1937) c. 231.

9 Mich. Comp. Laws (rg29) c. 252.

ro Minn. Stat. (Mason, rg27) c. 60.

II For the present remnants, see Cal. Civ. Code (Deering, I937) $\$ \$ 847-7$ I.

12 Mont. Rev. Codes Ann. (Anderson \& McFarland, I935) cc. I44-8.

${ }_{33}$ N.D. Comp. Laws Ann. (1913) c. 40, art. 5.

I4 Okla. Stat. (Harlow, I93r) c. 62. Is S.D. Code (I939) tit. 59. 
trust, and enacted in I6 states; ${ }^{16}$ the Uniform Principal and Income Act of $193 \mathrm{I}$, drawn by then Dean, now Judge, Charles Clark, disposing of principal and income questions regarding expenses and receipts, now adopted in eight states; ${ }^{17}$ the Uniform Trusts Act of 1937 , intended to make clear the extent of the loyalty duty, to abolish a few unfortunate rules and to relax for the sake of convenience certain restrictions on trustees, adopted in Louisiana ${ }^{18}$ and North Carolina; ${ }^{29}$ the Uniform Trustees' Accounting Act of I936, designed to outline the details of inventories and accounts by living and testamentary trustees, adopted in Indiana ${ }^{20}$ and Kansas; ${ }^{2 x}$ the Uniform Common Trust Fund Act of r938, which permits the establishment of common trust funds for investment purposes, adopted in North Carolina; $; 2$ the act prepared by title men providing that deeds to one as trustee, without mention of beneficiaries, give the trustee power to convey a fee, adopted in many states; ${ }^{23}$ the Bankers Collection Code, drawn and advocated by the American Bankers' Association, which provides a preference for collection items on the failure of a collecting bank, on trust theories but without regard to ability to trace, adopted in twenty-two states;"4 the "deposit in trust" statute, also sponsored by the Bankers' Association, permitting the bank of deposit to relieve itself of responsibility by paying to the beneficiary named in the title of the deposit, adopted in at least twenty-one states; ${ }^{25}$ the so-called trust administration act, drawn by $\mathrm{Mr}$. William Stevenson of Minneapolis, and enacted recently in Florida, ${ }^{26}$ which gives a trustee in substance the powers of a fee owner, unless the instrument excludes such powers; and the model spendthrift trust act, limiting such trusts to $\$ 5000$ annual income, prepared by Professor Griswold, ${ }^{27}$ and written into the Louisiana Trust Estates Act of 1938 .

In addition may be mentioned the almost universally prevailing trust investment statutes, the elaborate code in Georgia, ${ }_{2}^{28}$ and the Louisiana Trust Estates Act of $1938^{29}$ which reestablished trusts to a limited extent after their abolition by the Long administration.

My fifth reason for believing that this project constitutes a practical and desirable plan, is that the idea has already been approved in whole or in part Wyo.

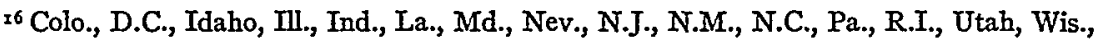

${ }^{17}$ Conn., Fla., La., Md., N.C., Ore., Utah, Va.

${ }^{88} \mathrm{La}$. Acts $\mathrm{r93} 8$, no. 8x.

${ }^{29}$ N.C.L. 1939, c. 197.
${ }_{23}$ For a discussion of these statutes, see White, The Title Man's Idea of Real Property Law Reform, Io Corn. L.Q. I8I (r925).

${ }^{24}$ See Program of State Legislation, published annually by the American Bankers' Association.

${ }_{25}$ For a collection of these statutes, see $x$ Bogert, Trusts \& Trustees 2r 3 (r935).

${ }^{26} \mathrm{Fla}$. Gen'l Acts 1937 , c. 18397 .

${ }^{28} \mathrm{Ga}$. Code ( $x_{933}$ ) tit. ro8.

${ }_{27}$ Griswold, Spendthrift Trusts 477 (I936).
${ }^{20}$ Ind. L. I937, c. I66.

${ }^{2 x}$ Kan. Prob. Code (x939) art. x6.

22 N.C.L. I939, §§ 4035aa-ff. 
by several organizations of high standing. Last spring, the Commissioners on Uniform Laws in Illinois urged the legislature to adopt the Uniform Principal and Income Act and the Uniform Trusts Act. Corporate fiduciaries were opposed to some provisions of these bills, although they agreed that some parts were desirable and some changes in Illinois trust law should be made. It was agreed by the Commissioners on Uniform State Laws and the corporate fiduciaries that these two bills be withdrawn from the I939 Illinois legislature on the understanding that the Commissioners and the corporate fiduciaries would enter into a co-operative project in I939, I940, and I94I, to examine carefully Illinois trust law for undesirable decisions and statutes, for uncertainties, for lack of law, and for other defects, with the purpose of framing a bill in I94I, which would remedy these deficiencies. This bill would be pressed before the legislature by the two groups. The work of research, discussion, and drafting would be done by a small committee containing representatives of the Corporate Fiduciaries Association of Chicago, the Illinois State Bankers Association, and myself as a member of the Commissioners on Uniform Laws and a student of trust law. The work of this committee has not as yet started. This paper is written partly in the hope of more definitely formulating a plan of work in Illinois, and partly with a desire to stimulate the formation of similar committees in other states.

Related ideas have of course been proposed from time to time and to some extent carried out. As long ago as I92I, the late Mr. Justice Cardozo wrote an article entitled "A Ministry of Justice," ${ }^{30}$ in which he urged that there should be an agency in each state to make a systematic study of the functioning of the law in its various departments and to recommend to the legislature changes when weaknesses were discovered. This article was the inspiration for the formation of the New York State Law Revision Commission which has been in operation since 1934. This Commission has made exhaustive studies of various branches of New York law and recommended bills to the legislature, some of which have been adopted. For example, in I937, the legislature passed a bill to make easier securing court approval of the sale, mortgage, and leasing of land by trustees, ${ }^{32}$ and also an act regarding the liability of corporate transfer agents with regard to the transfer of stock held in the name of a fiduciary. ${ }^{32}$ Both of these laws were preceded by detailed studies by the Law Revision Commission and both statutes were in the form drawn by the Commission. In 1938 an exhaustive report on the Rule against Perpetuities, Restraints on Alienation, and Spendthrift Trusts, was published by the New York Law Revision Commission with recommended legislation materially changing the law of New York on these subjects. ${ }^{33}$ This bill, however, has not yet met with the approval of the legislature.

${ }^{30} 35$ Harv. L. Rev. Ir3 (I92I).

${ }^{31}$ N.Y.L. I937, c. I4I.

${ }^{32}$ N.Y.L. I937, c. 344 .

${ }^{33}$ Reports of the New York Law Revision Commission 28I (1938). 
In I93 I the legislature of Delaware passed an act authorizing the governor to appoint a commission of nine to study the laws of the state regarding descent, distribution, the settlement of estates and the administration of trusts, with a view to the modernization and simplification of those laws. ${ }^{34}$ The governor appointed a commission of nine, representing trust men, the probate court, lawyers, and businessmen, which recommended several laws, some of which affected trusts, and these were adopted by the legislature. ${ }^{35} \mathrm{Mr}$. Gilbert Stephenson has described ${ }^{36}$ the history and procedure of this movement, both of which should be studied by any group which intends to accomplish a similar object.

In recent years there have been proposals in Minnesota and Oklahoma to revise and remodel trust law. It is understood that these efforts were sponsored exclusively by bankers and trust companies. So far these trust codes thus drawn have not been enacted. Reference has previously been made to the comprehensive Louisiana Trust Code of 1938 and the rather elaborate Florida Trust Administration Act of I937, both sponsored by bankers' associations.

In recent years the American Law Institute has announced that it would add to its function of restating the law that of drafting statutes to cure defects made patent in the course of the restatement. It has approved a property act ${ }^{37}$ (defining estates in land and other interests), an act regarding contribution among joint tortfeasors, ${ }^{38}$ an act relating to double jeopardy, ${ }^{39}$ and an act for summoning witnesses from outside the state. It cooperated for a time in drawing a code for aeronautics but dropped this work. The plans of the institute regarding future draftsmanship of statutes seem somewhat uncertain, being possibly dependent on future financial support. One defect in the institute's method of drawing statutes would seem to be the lack of adequate participation by business interests and specialists in the administration of the law in question.

It thus appears that the idea of revaluing and revising the law of trusts and other topics has a fair degree of prevalence. Many organizations have sponsored efforts of a limited extent in which the participation has not been broad in scope. It remains for a national organization of men particularly interested in the development of one branch of the law to apply the idea in a systematic way, state by state, and to call in the help of all interested parties. The Trust Division of the American Bankers' Association has this opportunity.

But it may be asked, admitting that trust law is mature, that it is ripe for reconsideration, that trust men are a group especially qualified to guide reconsideration, and that the idea of revaluing and readjusting trust law is taking hold here and there in America, just what good would come from such a project? How would it benefit anybody?

34 Del. L. I93r, c. 303.

${ }^{35}$ Del. L. 1935, c. 230.

${ }^{36}$ Stephenson, The Work of the Delaware Fiduciary Commission, 2 Univ. Chi. L. Rev. 6rg (I935).

37 I5 Proceedings of the American Law Institute I49, I93 (I938).

${ }^{38}$ I6 ibid. (I939).

${ }^{39}$ Io ibid., at Ior, I39 (I932). 
Preliminarily, it may be said that being a member of a state committee to inventory and revalue the trust law of that state would be a highly educational process and that if the report of the committee were published and distributed to trust men and some lawyers the educational work would be considerably expanded. We would all get a much clearer picture of the trust law of our own state in its relation to trust law generally. Even if no reformatory statute were deemed necessary or could be adopted, a very convenient tool for guiding trust creation and management would have been created.

But, beyond that, it is my belief that in almost all states there would be discovered at least a small number of opportunities for beneficial change. I doubt if in any state the work would show a need for a comprehensive code. The proposed statutes might run from five to fifty sections.

What types of defects would be found and could be cured? There are, first, a few unfortunate decisions of the courts which should be erased as precedents. For example, in Illinois we have the famous case of Bohleber v. Rebstock, $4^{\circ}$ which refused to fasten a constructive trust on sons who were devisees in their father's will and who prevented the father from changing his will so as to give his property to other relatives. Surely this was an example of acquiring property by reprehensible conduct, the recipe for a constructive trust. And in Iowa we have Ober v. Dodge, ${ }^{4 \mathrm{I}}$ which held that where a trust beneficiary could elect to take whatever income she liked, until she demanded income there was nothing for creditors. The difference between a power to take at will and vested ownership seems specious. States which find their local rule to be that of a small minority of states may wish to consider whether experience should lead them to join the larger group. Thus, perhaps Texas and North Carolina might find that their lack of a seventh section of the Statute of Frauds and consequent support of oral trusts of land has been unfortunate; or Kentucky might wish to follow the lead of Alabama42 in giving at least limited validity to spendthrift trusts instead of holding such restraints on alienation void.

Secondly, uncertainties in the common law could be cleared up. The Restatement of the Law of Trusts says ${ }^{43}$ that a spendthrift trust provision cannot protect the right of a beneficiary to trust capital but only to trust income. Scott ${ }^{44}$ states that this is the better view, but cites no cases as backing it. And yet the typical trust instrument provides that neither right to income nor capital shall be alienable by the beneficiary or subject to his debts; trust men appear generally to believe that this clause is valid in its entirety; and recent decisions in California, Minnesota and Texas are to this effect. ${ }^{45}$ In most states there are no decisions on this point.

${ }^{40} 255$ Ill. 53,99 N.E. 75 (I9I2).
$\begin{aligned} & { }^{4} 2 \text { Io Iowa } 184,23 \text { I N.W. } 444 \text { (I930). } \\ & { }^{42} \text { Ala. L. I935, no. } 230 .\end{aligned}$
${ }_{45}$ Coughran v. First Nat'l Bank, I9 Cal. App. (2d) 152,64 P. (2d) Ior3 (I937); Erickson v. Erickson, x97 Minn. 7I, 266 N.W. r6r (I936); Norman v. Jenkins, 73 S.W. (2d) I05I (Tex. Civ. App. 1934). 
Then, there are doubts and queries arising from ambiguities in existing statutes. For instance, in Ohio the probate code ${ }^{4}$ in its literal terms applies only to trustees appointed by and accountable to the probate court. Will the courts construe the statute as governing trustees of living trusts, or will they say that the common law controls the latter and thus some acts which are lawful for one type of trustee are unlawful for another? In other states there are elaborate trust codes applying to banks and trust companies, 47 but making no mention of individual trustees. Are the latter impliedly included or are they governed by the common law?

Some statutes on trusts have received violent adverse criticism and are often treated as vestiges of an outgrown system. For example, the New York statute restricting the purposes of express private trusts of land to four ${ }^{4^{8}}$ is generally condemned in New York, and statutes following it in California, ${ }^{49} \mathrm{Minnesota}^{50}$ and other states have in substance been repealed. The desire of the revisers of 1830 in New York to restrict the use of real property trusts has given way to a feeling that trusts should be usable for any convenient object. This and similar relics of the early days are ripe for repeal.

Again, a state may wish to consider whether a rule of trust law now applicable by court rule to part of the state only should be made statewide in effect. In Illinois in at least one judicial district, trustees by court rule are required to file annual reports ${ }^{5 x}$ in court while in the other districts no periodic court accounting is required and trustees account in court only when a bill in equity is filed by themselves or by a beneficiary. Is there justification for this difference?

Furthermore, in all except the very old, large, and populous states, there are many points of trust law on which there is no local decision, the cases in other jurisdictions are sometimes conflicting, and practices among professional trustees differ. Thus, most states have only a few decisions on capital and income questions. I doubt whether in Illinois one-fourth of the important problems in reference to the allocation of expenses and receipts to principal or income accounts have been passed upon by the appellate courts. Some trustees lean towards favoring the life tenant as nearest to the testator and as before the eyes of the trust officer, while other corporate fiduciaries decide for the remainderman in cases of doubt on the theory that mistaken allotments to capital can generally be corrected but an erroneous payment to a life tenant is often irrevocable. Thus, occasionally, the kind of trust law one gets as beneficiary or remainderman depends on the settlor's selection of his trustee.

${ }^{46}$ Ohio Code Ann. (Throckmorton, I936) \& ro5og.

${ }^{47}$ Wash. Rev. Stat. Ann. (Remington, 1932) $\$ 3255$.

${ }_{48}^{8}$ N.Y. Real Property Law $\S 96$.

${ }^{49}$ Cal. L. 1929, c. 146.

50 Minn. Stat. (Mason, I927) § 809o (6).

${ }^{5}$ Rule of Circuit Courts, 7 th Circuit, quoted in I Bogert, Trusts and Trustees 59 (Supp. 1938). 
One could go on at some length giving instances in which a critical comparison of local trust law with trust law in general would bring to light uncertainties, mistakes, anachronisms and gaps in the law. Some of these are of minor importance and may be ignored or left to correction by the discretion of the chancellor; but others are real handicaps to trust creation or administration, involve expense occasionally by reason of the necessity of going to court, sometimes cause liability on the part of trustees, and have some effect in discrediting the trust institution among settlors, beneficiaries, and the public in general. It is submitted that a movement which would abolish the major part of these defects in the course of a few years is worthy of the support of trust men and lawyers.

An important difference may be noticed between this project and some other movements for statutory change, as, for example, those of the Uniform Law Conference and the American Law Institute. Here it is not suggested that trust law should be the same in all states, or that a single uniform reform statute be drawn and urged on all legislatures. It is recognized that the histories and economic and social conditions of the states are very different, that trust law is largely of local concern, and that consequently the trust law which suits one may be unsatisfactory to another. It is merely suggested that each of the forty-eight states examine and criticize its own trust law, in the light of the experience elsewhere and of proposed model laws, and then decide what, if any, revision or amplification is needed locally.

Observe, also, that this project would have another important difference from the usual program of law reform. It would not be in the hands of a single interest, but would be the work of representatives of all interested parties, as far as may be. While it is suggested that the Trust Division of the American Bankers' Association head the movement and guide its progress through the various states, it is strongly urged that the state trust groups add to the working committee individuals who could stand for settlors, beneficiaries, and the public in general. If trust men can persuade the legislatures and the governors to sanction and appoint the committees, as was done in Delaware, the plan will obviously have the best possible backing; but if for any reason such official sponsorship is deemed impracticable it is believed that the state trust division can effectively guide the movement into impartial consideration of the law.

In the field of trusts there are a number of groups which should have a part in any revaluation and readjustment of trust law. There are, first, the professional trustees, both corporate and individual; secondly, lawyers who specialize in trust law as advisors to trustees, or as draftsmen for settlors, or as counsel to beneficiaries; thirdly, judges who deal frequently with trust problems, in the probate or equity courts; fourthly, teachers and writers who have a major interest in the subject. Would it not be possible to form in each state a small committee with representatives of each of these four interests? In that way all trust parties would have at least some representation. The likelihood of a 
statute which seemed to be, or in fact was, biased or partial would be reduced. The legislature would have more confidence in the resulting recommendation than if a single interest had presented the bill. Possibly the American Law Institute could be persuaded to cooperate and to delegate its assistance to the local draftsman of the annotation to the Restatement of Trusts. Possibly the National Conference of Commissioners on Uniform State Laws, which has the function of drafting model laws as well as proposed uniform codes, would select one of its local commissioners to represent it officially. Possibly the local statutory reviser, or state reference librarian, or bill draftsman, could be made available during the later stages of the work.

The movements for reform or codification of trust law under the auspices of bar associations, law revision commissions, the American Law Institute, and bankers associations, all seem to have the defect of lack of complete representation. The discussers and draftsmen are often looking at the problem merely as lawyers, or merely as businessmen, or merely as students of the printed law. Could not the Trust Division of the Bankers' Association sponsor a project with a broader base, which would truly consider the public interest and so command general confidence?

If we can imagine the Trust Division of the American Bankers' Association urging the trust divisions of state bankers' associations to initiate projects for reexamination of trust law, state by state, in the light of the restatement, the recent texts, current practice, and local law; and if we can concede that the state organizations could procure the formation of committees of perhaps five in each state consisting of two trust company or bank men, one lawyer in general practice, one judge, and one teacher specializing in trusts, how would such a committee proceed?

First, I would suggest that if the work of annotating the Restatement of Trusts with local decisions and statutes has not yet been completed, the committee get into contact with the man or group doing this work and stimulate and assist him or them. The local annotator might well be a member of the committee to reconsider the state law of trusts. The restatement annotations, with the restatement, the leading general texts, and any local books on trust law, might well be the initial research library of the committee.

Secondly, the committee should send out a request to local lawyers and trust men for suggestions as to unsatisfactory conditions and needed changes. Probably best results will be obtained if the subject is outlined by topics and several questions are asked under each heading, instead of simply putting out the single query whether the addressee has any suggestions to make. Thus, the topic of investments could be segregated and questions asked about retention of the settlor's investments, the satisfactoriness of the statutory list, reviewing duties, etc.

Thirdly, the hard work of examining local case and statute law in comparison with general trust law should be parcelled out to the committee members, 
to be done by the use of the restatement, the local annotations to it, the texts, and local digests. Reports by the committee members on their several parts of the subject should be considered by the whole committee, as should the answers to any questionnaire or letter of inquiry distributed to fiduciaries, lawyers, judges, and teachers of the subject.

It would then be expected that the findings and conclusions of the committee regarding the state of trust law, and recommendations for action, would be printed for criticism by lawyers and businessmen affected. Following consideration of criticisms of this report, the committee could draft any statute which seemed to be indicated as desirable, subject it to wide opportunity for discussion and comment, and then secure its introduction in the legislature. It is reasonable to expect that an act so drawn might receive support from bar associations, as well as from the state bankers' associations.

The expense of such a survey ought not to be great. There need be no salaries to the committee members. It is believed that many well qualified persons would be willing to serve without compensation. Much of the work could be conducted by correspondence. Occasional meetings could be arranged in connection with state bar or bankers' association meetings. The only outlays of considerable size would be for office supplies and records and for the cost of printing and distributing reports and findings. But these expenditures should be relatively slight, considering the value of the product.

To me, this project appeals as a timely opportunity for constructive service to present and future trust parties, and so to our society as a whole. 